\title{
Identification and Measurement of Carbonic Anhydrase-II Molecule Numbers in the Rat Carotid Body
}

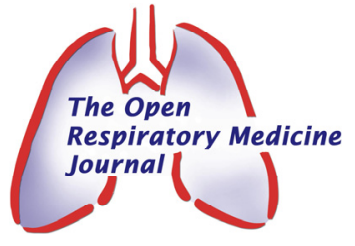

\author{
Guglielmo Di Tano ${ }^{1}$, Claudia Petrarca ${ }^{1}$, Gerardo Bosco ${ }^{1}$, \\ Pasquale Battista $^{2}$, Zhongjin Yang ${ }^{*}, 3$, Luca Morelli ${ }^{1}$, \\ Renato Barbacane ${ }^{4}$ and Bruno Loffredo ${ }^{1}$
}

\author{
${ }^{I}$ Department of Basic and Applied Medical Sciences, G. d'Annunzio University of Chieti-Pescara, School of Medicine, \\ Chieti, Italy \\ ${ }^{2}$ Motor sciences, University of Chieti, Chieti-Pescara, Italy \\ ${ }^{3}$ Institute for Human Performance, Upstate Medical University, Syracuse, NY, USA \\ ${ }^{4}$ Immunology Division, G. d'Annunzio University of Chieti-Pescara, School of Medicine, Chieti, Italy
}

\begin{abstract}
Carbonic anhydrase (CA) in the carotid body (CB) plays an important role in the maintenance of blood $\mathrm{PO}_{2}$ and $\mathrm{PCO}_{2} / \mathrm{pH}$ homeostasis by regulating ventilation. It has been observed that the activity of $\mathrm{CA}$ in the rabbit $\mathrm{CB}$ is stronger under hypoxic conditions than under normoxic and hyperoxic conditions. In conditions of chronic hypoxia, the volume of the CB increases significantly because the number of type I and II cells increases. So far, the number of CA molecules in the $\mathrm{CB}$ has not been assessed. We develop a technique to quantify the number of CA molecules in the CB. The CBs were dissected out from 8 rats, immediately frozen with liquid nitrogen, pulverized and centrifuged. The proteins extracted from CB tissue were heat-denatured and separated by electrophoresis on a $12.5 \%$ denatured-polyacrylamide gel (SDSPAGE); a $31 \mathrm{kDa}$ protein band was determined which reacted with a rabbit polyclonal antibody specific for rat CA-II in Western blot analysis. The immunoreactive $31 \mathrm{kDa}$ CA-II protein was detected and quantified by laser scanner densitometry-using ${ }^{125}$ I-rProtein A as a tracer. The mean ${ }^{125}$ I radioactivity emitted by the antibody bound CA-II was 31277 $\mathrm{cpm}$. This value corresponds to $4.57 \mathrm{ng}$ CA-II. When compared with a rat CA-II calibration curve, an average of number of $3.54 \times 10^{7}$ CA-II molecules were quantified for $1 \mu \mathrm{g}$ of whole $\mathrm{CB}$ tissue. This is a sensitive and accurate radioimmunoassay technique and may be useful in future studies on the role of CA-II in different pathophysiologic conditions
\end{abstract}

Keywords: Carbonic anhydrase, Carotid body, Phosphor imaging, SDS-PAGE, Western blot.

\section{INTRODUCTION}

The carotid body (CB), alternatively called "carotid glomus", is a small cluster of chemoreceptors and supporting cells located near the bifurcation of the carotid artery. The main function of the $\mathrm{CB}$ is to maintain homeostasis of blood oxygen partial pressure $\left(\mathrm{PO}_{2}\right)$, carbon dioxide partial pressure $\left(\mathrm{PaCO}_{2}\right)$, and acid-base balance by regulating ventilation. The chemoreceptors in the $\mathrm{CB}$ are innervated by a branch of the glossopharyngeal nerve, which projects to the respiratory center in the brainstem. A decrease in arterial $\mathrm{PaO}_{2}$ or an increase in $\mathrm{PaCO}_{2}$ and acidity, when detected by the chemoreceptors, stimulates the $\mathrm{CB}$ nerve and activates a respiratory reflex, which leads to an increase in ventilation so as to restore normal blood $\mathrm{PO}_{2}$ and $\mathrm{PCO}_{2} / \mathrm{pH}$. The rapid response of the $\mathrm{CB}$ to changes in $\mathrm{PaCO}_{2} / \mathrm{pH}$ depends on the function of carbonic anhydrase (CA), an enzyme found in many mammalian cells and tissues, including the $\mathrm{CB}[1,2]$. $\mathrm{CA}$ catalyzes the hydration of $\mathrm{CO}_{2}$ to facilitate the rapid

*Address correspondence to this author at the Department of Anesthesiology, SUNY Upstate Medical University, Syracuse, New York, 13210. USA;; E-mail: yangz@upstate.edu restoration of normal intracellular $\mathrm{pH}$ in response to the changes in extracellular $\mathrm{PaCO}$. This chemical stimulus is coupled with a release of neurotransmitters from the $\mathrm{CB}$ that generates action potentials in the central nervous system's afferent nerve terminal.

$\mathrm{CA}$ was first identified in the $\mathrm{CB}$ by Lee and Mattenheimer in 1964 [3], and at least 14 distinct CA isozymes have been identified currently [4]. According to their cellular localizations, these isozymes have been characterized into four broad aubgroups, which, in turn consist of several isoforms: the cytosolic CAs (CA-I, CA-II, CA-III, CA-VII and CA XIII), mitochondrial CAs (CA-VA and $\mathrm{CA}-\mathrm{VB}$ ), secreted CAs (CA-VI) and membraneassociated CAs (CA-IV, CA-IX, CA-XII, CA-XIV and CA$\mathrm{XV}$ ) [5]. CA-II is found in the cytosol of cells in numerous organs. In the CB, CA-II is found in glomus or type I cells, as well as in the nerve bundles. It may also exist in vascular smooth muscle cells [6]. In the $\mathrm{CB}$, the catalytic activity of CA-II isozyme is stronger than that of the other two isozymes expressed at this anatomical site, CA-I and CA-III. In the rabbit, it has been observed that the whole CA activity in the $\mathrm{CB}$ is stronger under hypoxic condition than under 
normoxic and hyperoxic conditions [7]: However, it is still unknown whether the hypoxia-related increase in CA activity is due to increase in the specific activity of CA molecule or increase in the number of CA molecules, or both mechanisms. It would help us to better understand the role of $\mathrm{CA}$ in the maintenance of homeostasis if the number of CA molecules could be sensitively and accurately quantified.

This leads us to develop a new technique to quantitatively measure the numbers of CA molecules in the CB by using Western blot (WB), SDS-PAGE electrophoresis and indirect radioimmunoassay techniques.

\section{METHODS}

\section{Tissue Collection}

The proposed study was approved by Chieti University's Ethical Committee for the Use of Animals and was conducted in accordance with the guidelines established by the US National Institutes of Health. Eight pathogen-free female Wistar rats (Charles River Laboratories, Inc. Wilmington, MA) weighing between 250-300 gram were used. All rats were anesthetized by intraperitoneal injection of $40 \mathrm{mg} / \mathrm{kg}$ pentobarbital sodium. A longitudinal incision was made in the middle cervical skin, and the regions of the carotid bifurcation were surgically exposed. Then, a left thoracotomy was made to expose the heart. A modified Tyrode's solution (N-2-hydroxyethylpiperazine-N'-2ethanesulfonic acid/ $\mathrm{NaOH}, \mathrm{pH}$ 7.4) equilibrated at a given $\mathrm{PO}_{2}$ of 20 Torr at $37^{\circ} \mathrm{C}$ ) was perfused through the heart, maintaining the temperature at $35.5+/-0.5{ }^{\circ} \mathrm{C}$, until the efferent perfusate was blood-free [1]. Then, CBs were quickly dissected out and placed on a Petri dish with ice cold Tyrode's solution to remove the surrounding fat and connective tissue under a binocular microscope. Residual blood cells were carefully removed by osmotic shock and washing with MilliQ $\mathrm{H}_{2} \mathrm{O}$. Finally, the $\mathrm{CBs}$ were frozen with liquid nitrogen, until further process for CA-II assay.

\section{Preparation and Determinations of Protein Extract}

Frozen CB samples were pulverized using a micro-pestle of borosilicate glass, while kept in liquid nitrogen, and homogenized in ice-cold Laemmli buffer $(2 \%$ sodium dodecyl sulphate, $10 \%$ glycerol, $5 \%$ 2-mercaptoethanol, 62.5 $\mathrm{mM}$ Tris $\mathrm{HCl}, \mathrm{pH}$ 6.8) [8] mixed with protease inhibitor cocktail at 1:100 (P8340 Sigma-Aldrich). CB weights were obtained by subtracting the weight of the homogenization buffer from the weight of the each $\mathrm{CB}$ homogenate. Then, the tissue homogenates were incubated at $4^{\circ} \mathrm{C}$ for 1 hour with gentle agitation and centrifuged at $12000 \mathrm{rpm}$ for 20 minutes, at $4^{\circ} \mathrm{C}$. The protein concentration in the supernatant was determined using a BCA protein assay kit (Pierce Chemical, Rockford, IL), according to the enhanced protocol (linear range of detection of $5-250 \mu \mathrm{g} / \mathrm{ml}$ of protein).

\section{Antiserum}

Rabbit antiserum to purified (SDS-denatured) rat CA-II isozyme was generously provided by Dr S.J. Dodgson (Department of Physiology, School of Medicine, University of Pennsylvania). Preparation of the immunogen, immunization regimen, serum preparation and characterization according to description of Dodgson and his colleagues $[9,10]$. For Western blot analysis, the rabbit polyclonal anti-CA II antibody reacted specifically with the rat and bovine isozyme CA-II [8]. Determination of standard curves and radioimmunoassay to assess maximum binding of CA-II in the presence of antibody excess were performed as described by Jeffery et al. [9].

\section{Purified Rat CA-II}

Purified rat CA-II was kindly provided by Dr. Dodgson. Briefly, the rat CA-II isozyme was purified from rat hemolysate by affinity chromatography on sulfonamide columns [11] (ProntoSIL).

Amino acid analysis of the putative CA-II was performed by trypsin digestion and amino acid terminal sequence according to Linder et al. [12]. The $\mathrm{CO}_{2}$ hydration activity of the $31 \mathrm{kDa}$ protein from rat hemolysate was determined using a potentiometric assay as described by Wistrand and Wahlstrand [13].

\section{Electrophoretic Separation of CB Protein Extract and Identification of CA-II}

Equal amounts of lysates containing $250 \mu \mathrm{g}$ of $\mathrm{CB}$ cytoplasmic proteins extract (in $30 \mu \mathrm{l}$ ) were added with $5 \mathrm{x}$ running buffer (final concentration: $50 \mathrm{mM}$ Trishydrochloride $\mathrm{pH} 6.8,10 \mathrm{mM}$ dithiothreitol, $2 \%$ SDS, $10 \%$ glycerol, $0.001 \%$ bromophenol blue) heat-denatured (at $95^{\circ} \mathrm{C}$ for $5 \mathrm{~min}$ ) and electrophoresed trough a $12.5 \%$ SDSpolyacryl-amide gel.

For determination of the relative motilities (relative molecular weight $\left[\mathrm{M}_{\mathrm{r}}\right]$ ), marker polypeptides were also electrophoresed with protein samples, in a non contiguous lane to avoid contaminations, and blotted to nitrocellulose, namely: rabbit muscle phosphorylase $\mathrm{b}(97.4 \mathrm{kDa})$, bovine serum albumin (66.2 kDa), hen egg-white albumin (45 kDa), bovine carbonic anhydrase $(31 \mathrm{kDa})$, soybean trypsin inhibitor $(21.5 \mathrm{kDa})$, and hen egg white lysozyme (14.4 kDa) (Bio-Rad Laboratories, Richmond, CA). Densitometer tracings of the unstained polyacrylamide gel at $280 \mathrm{~nm}$ were obtained by a Photovolt Densitometer Model 520 A (Photovolt Corporation, New York, NY). The absolute integrated optical density of each band was analyzed by GelPro analyzer software (MediaCybernetics, Silver Spring, $\mathrm{MD})$, which allowed to calculate the molecular weight of the unknown bands in the CB samples.

\section{Electroblotting and Indirect Radioimmunoassay of CA-II}

Following the electrophoresis, rat CB protein (from 250 $\mu \mathrm{g}$ tissue) was transferred from the gels on to Protran nitrocellulose membrane $(0.1 \mu \mathrm{m}$, Scheiler \& Schuell, Dassel, Germany, Cat. No. 401180) by electroelution using a Transblot apparatus (Bio-Rad Laboratories, Hercules, CA) at $100 \mathrm{~mA}(30 \mathrm{~V})$ overnight, at $4^{\circ} \mathrm{C}$. For transfer, the gel was soaked in the blotting buffer (Tris/glycine, $\mathrm{pH}$ 7.4, containing $20 \%(\mathrm{v} / \mathrm{v})$ methanol) and placed in a sandwich made up of filter paper soaked in $0.5 \%$ SDS, the gel, nitrocellulose membrane and filter paper soaked in the blotting buffer. The efficiency of electrotransfer of proteins was checked by staining the gels after transfer with Coomassie brilliant blue R-250 (ICN Biomedicals, Aurora, $\mathrm{OH})$ and analyzing the gel by densitometry.

The nitrocellulose sheet was washed and first incubated overnight at $4{ }^{\circ} \mathrm{C}$ with blocking buffer $(3 \%$ bovine serum 
albumin Fraction $\mathrm{V}$ in NTE-NP40 $(150 \mathrm{mM} \mathrm{NaCl}, 50 \mathrm{mM}$ Tris- $\mathrm{HCl}, \mathrm{pH} 7.5,2 \mathrm{mM}$ EDTA, 0.1\% Nonidet-P40; all chemicals from Sigma, St. Louis, MO); then the membranes were sealed in plastic bag containing a 1:100 dilution of rabbit anti-rat CA-II antiserum [8], for $3 \mathrm{~h}$ at room temperature, on a rocking platform. Thereafter, the membrane was washed three times with NTE-NP40 for 10 min and then incubated in $2 \mathrm{ml}$ of blocking buffer containing $20 \mu 1{ }^{125} \mathrm{I}$-rProtein A ( $2 \times 10^{5} \mathrm{cpm} ; 50 \mathrm{ng}$; NEX-146 stock $10^{7}$ $\mathrm{cpm} / \mu \mathrm{g}$; Perkin Elmer, Waltham, MA) for $1 \mathrm{~h}$ at room temperature. Protein A reacts with most common $\mathrm{IgG}$ subclasses and is therefore suitable for direct autoradiographic detection of membrane-bound antibody in western blotting applications with low background binding and signal. After $1.5 \mathrm{~h}$ incubation, the unbound ${ }^{125} \mathrm{I}$-rProtein A was removed by washing with NTE-NP40 three times at $37^{\circ} \mathrm{C}$ for $2 \mathrm{~h}$.

The membranes were exposed for 3 days to a high-density phosphor imaging screen (Bio-Rad Laboratories), which captures latent images produced by the $\gamma$ emissions of the ${ }^{125} \mathrm{I}$ radioisotope. Upon laser-induced stimulation, light was emitted from the storage phosphor screen in proportion to the amount of radioactivity in the sample. Wide linear dynamic range ( 5 orders of magnitude) enables quantitation and visualization of both weak and strong signals in a single exposure. After digitalization of the results, the screen was exposed to extra-bright light of ImageEraser light box and reused. A laser scanning densitometer (GS-250 Molecular Imager System; Bio-Rad Laboratories, Hercules, CA) was used to convert the radioactive signals emitted by the immunoreactive areas on the phosphor screen into digital images for subsequent densitometric analysis by the software package Phosphor Analyst (Bio-Rad Laboratories, Hercules, CA) [14]. The radioactive signal emitted by unloaded parallel lanes in the same gel was considered as background. CA-II quantitation was performed 4 independent experiments.

\section{Calibration Curve for CA-II Assay}

Aliquots of purified rat CA-II (kindly provided by Dr Dodgson, University of Pennsylvania) were used to define a calibration curve for rat CB CA-II. Escalating known concentrations of purified CA-II isozyme $(0.625,1.25,2.5$, 5 , and $10 \mathrm{ng}$ ) were eletrophoresed, blotted and detected (as described in the previous paragraph) using various combinations of concentrations of anti-CA-II antibody and calibration curves were drawn and detected with 1:100 antiCA II antibody and $50 \mathrm{ng}{ }^{125} \mathrm{I}$-rProtein A (stock at $10^{7}$ $\mathrm{cpm} / \mu \mathrm{g}$; NEX-146, Perkin Elmer, Waltham, MA, USA). Assay accuracy was evaluated from 3 replicas of the experiment.

\section{RESULTS}

The weight of each CB ranged from 50 to $80 \mu \mathrm{g}$ (mean $=$ $63 \mu \mathrm{g}$, S.D. $=10)$, for a total CB weight of $1015 \mu \mathrm{g}$ as shown in Table $\mathbf{1}$.

The proteins were extracted from $16 \mathrm{CB}$ (in 8 rats) and analyzed by SDS-PAGE electrophoresis to verify the presence of the CA-II isozyme. Under denaturing conditions, the electrophoresis revealed a broad spectrum of protein bands according to the different molecular weights. As shown in Figs. $(\mathbf{1}, \mathbf{2})$, a band at the position of $31 \mathrm{kDa}$ molecular weight was revealed, which represents the CA-II isozyme, as evidenced by the standard control marker. This method enabled us to obtain quantitative data by measuring

Table 1.

\begin{tabular}{|c|c|}
\hline Normal Wistar Rat & Carotid Body Weights Weight \\
\hline CB No. & CB Weight $(\mu \mathrm{g})$ \\
\hline $1^{\circ}$ & 58 \\
\hline $1 \mathrm{~B}$ & 61 \\
\hline $2^{\circ}$ & 72 \\
\hline $2 \mathrm{~B}$ & 76 \\
\hline $3^{\circ}$ & 50 \\
\hline $3 \mathrm{~B}$ & 54 \\
\hline $4^{\circ}$ & 74 \\
\hline 4B & 61 \\
\hline $5^{\circ}$ & 80 \\
\hline $5 \mathrm{~B}$ & 71 \\
\hline $6^{\circ}$ & 51 \\
\hline $6 \mathrm{~B}$ & 55 \\
\hline $7^{\circ}$ & 53 \\
\hline $7 \mathrm{~B}$ & 59 \\
\hline $8^{\circ}$ & 68 \\
\hline $8 \mathrm{~B}$ & 72 \\
\hline Total weight weight $(\mu \mathrm{g})$ & 1015 \\
\hline Mean & 63 \\
\hline S.D. & 10 \\
\hline
\end{tabular}

the radioactivity emitted by the complex formed by ${ }^{125} \mathrm{I}$ rProtein A+antibody+CA-II isozyme. Protein A binds to the Fc region of mammalian immunoglobulins, including rabbit IgG in a 1:1 molar ratio [15], in turn, IgG molecules owns two antigen binding sites. Therefore, the number of CA-II molecules bound to ${ }^{125} \mathrm{I}$-rProtein A could be calculated from the radioactivity detected by the imaging screen as shown in Fig. (2). By laser scanning densitometry we measured a mean of $31277 \mathrm{cpm}$ emitted by the $31 \mathrm{KDa}$ immunoreactive band, i.e. by ${ }^{125}$ I-rProtein A; such radioactivity value corresponds to $3.1 \mathrm{ng}{ }^{125} \mathrm{I}$-rProtein A. Making the assumption that the molar ratio of the complex ${ }^{125}$ I-rProteinA-Antibody-CAII is $1: 1: 2$, and considering the corresponding apparent molecular weights, 4.6 ng CA-II was estimated ([3.1 ng/42000 $\left.\mathrm{Da}{ }^{*} 31000 \mathrm{Da}^{*} 2\right)$. Therefore, since 1 molecule mass equals $31 \mathrm{kDa}$, that is $5.15 \times 10^{-11} \mathrm{ng}$, the deduced number of CA-II molecules within the immunoreactive band is $4.6 \mathrm{ng} / 5.15 \mathrm{x}$ $10^{-11} \mathrm{ng}=8.84 \times 10^{10}$; that is, approximately $3.54 \times 10^{7}$ molecules $/ \mu \mathrm{g}$ CB tissue.

In order to verify the accuracy of our radioimmunoassay for $\mathrm{CA}-\mathrm{II}$ in the rat $\mathrm{CB}$, we defined also a calibration curve for CA-II as shown in Table 2 and Fig. (3). A linear correlation between protein amounts and detected 


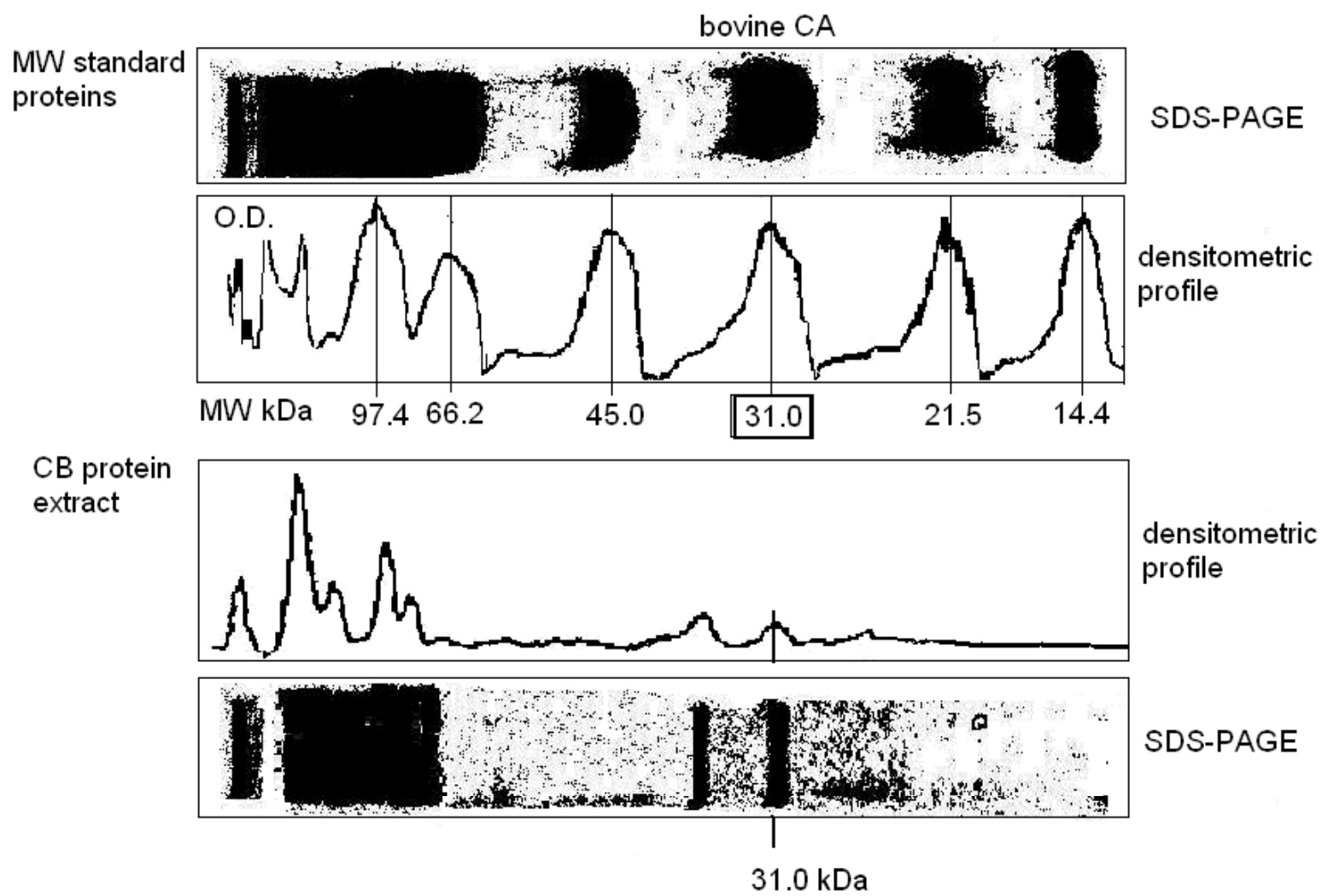

Fig. (1). SDS-PAGE and Densitometry analysis of carbonic anhydrase II. The densitometric profile in upper figure shows the standard peak optical density and distance from the start point, which represents different molecular weight protein and corresponds to SDS-PAGE detected proteins. The standard CA-II protein is at the position $31.0 \mathrm{kDa}$ band. Lower figure shows the peaks and distances of immunoreactive proteins extracted from carotid body obtained by SDS-PAGE. An immunoreactive protein peak showed at position $31 \mathrm{kDa}$ confirms the presence of CA II in rat carotid body. Only the molecular weight region between 97.4 and $14.4 \mathrm{kDa}$ is shown.

radioactivity was found in the range $0.625-10 \mathrm{ng}$ CA-II $\left(\mathrm{R}^{2}=0.9958\right)$.

A linear relationship between ${ }^{125} \mathrm{I}$ radioactivity and the amount of standard CA-II was obtained using 1:100 dilution antibody dilution and $50 \mathrm{ng}{ }^{125}$ I-rProtein A (stock $10^{7}$ cpm/ $\mu \mathrm{g}$; NEX-146, Perkin Elmer, Waltham, MA, USA). When control serum from non immune rabbit was used instead of the rabbit anti rat CA-II, no protein band was detected (data not shown).

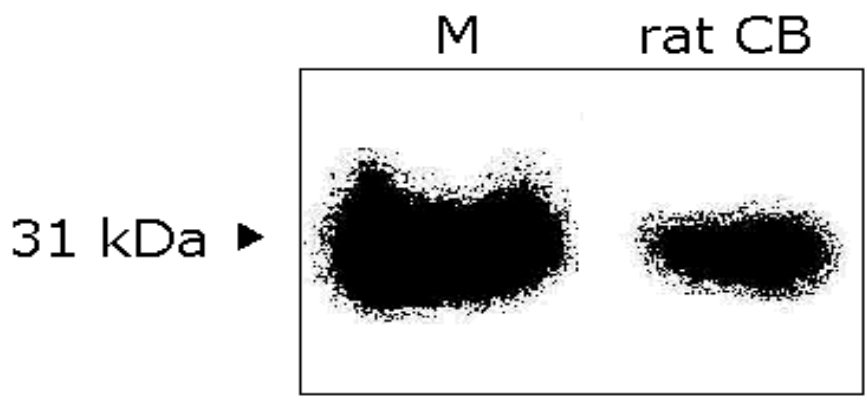

Fig. (2). Western blot analysis of carbonic anhydrase II. The digital image of immunoreactive band from rat $\mathrm{CB}$ extract is at position of $31 \mathrm{kDa}$, which represents the CA-II, as evidenced by the standard bovine carbonic anhydrase-II marker. CB: carotid body; M: standard control marker.
Table 2.

\begin{tabular}{|c|c|}
\hline \multicolumn{2}{|c|}{ Calibration Curve } \\
\hline Purified CA-II (ng) & ${ }^{{ }^{25} \text { I Radioactivity (cpm) }}$ \\
\hline \hline 2.0 & 13639 \\
\hline 3.5 & 24145 \\
\hline 5.0 & 31277 \\
\hline 6.5 & 41437 \\
\hline 8.0 & 46916 \\
\hline
\end{tabular}

As shown in Table 3, the weights of calculated CA-II according to calibration curve were very close to detected (observed) CA-II from the radioactivity data with an accuracy of 0.098 .

\section{DISCUSSION}

The homeostasis of blood $\mathrm{PO}_{2}$ and $\mathrm{PCO}_{2} / \mathrm{pH}$ is well maintained via the control of ventilation under normal physiological conditions. Either the decrease in arterial $\mathrm{PO}_{2}$ or the increase in $\mathrm{PCO}_{2}$ and acidity stimulates the respiratory center of the brainstem resulting in an increase in ventilation and restoration of blood $\mathrm{PO}_{2}$ and $\mathrm{PCO}_{2} / \mathrm{pH}$. The chemoreceptors located in the $\mathrm{CB}$ play an important role in 


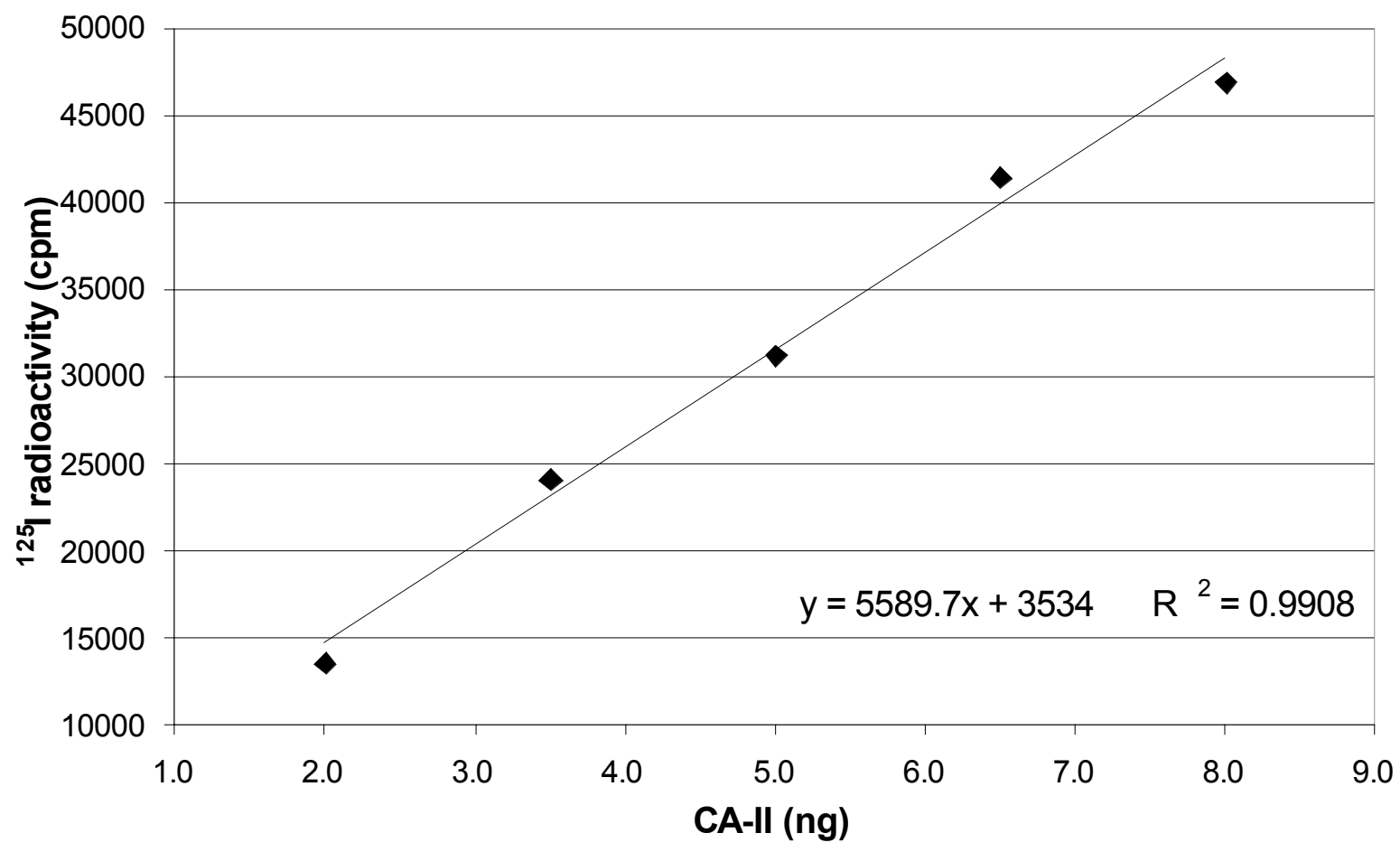

Fig. (3). Correlation between ${ }^{125}$ I radioactivity and amount of standard carbonic anhydrase. The figure shows a positive linear relationship between ${ }^{125}$ I radioactivity reading $(\mathrm{cpm})$ and carbonic anhydrase weight $(\mu \mathrm{g})$. Data are represented as mean value of three independent curves.

rapid response to a change in blood $\mathrm{PCO}_{2}$ and $\mathrm{PaCO}_{2} / \mathrm{pH}$ mainly mediated by the CA activity.

Table 3.

\begin{tabular}{|c|c|c|c|}
\hline \multirow{2}{*}{$\begin{array}{c}\text { CB Sample } \\
(\mathbf{2 5 0} \boldsymbol{\mu g})\end{array}$} & \multirow{2}{*}{\begin{tabular}{c}
$\mathbf{1 2 5}_{\mathbf{I}} \mathbf{( \mathbf { p m } )}$ \\
\cline { 3 - 4 }
\end{tabular}} & & \multicolumn{2}{|c|}{ CA-II } \\
\hline \hline 1 & 31017 & 4.5 & 4.9 \\
\hline 2 & 31512 & 4.5 & 5.0 \\
\hline 3 & 32133 & 4.6 & 5.1 \\
\hline 4 & 32847 & 4.7 & 5.2 \\
\hline Mean & 31877 & 4.6 & 5.1 \\
\hline S.D. & 791 & 0.096 & 0.129 \\
\hline
\end{tabular}

Accuracy: $(5.1-4.6) / 5.1=0.098$.

(1) $y=5589.7 x+3534$.

$\mathrm{CA}$ is an enzyme of $31 \mathrm{kDa}$, whose active site contains a zinc atom. CA catalyzes the reversible hydration-dehydration of $\mathrm{CO}_{2}-\mathrm{HCO}_{3}^{-}$. Since $\mathrm{CA}$ activity speeds up the reaction between $\mathrm{CO}_{2}$ and $\mathrm{H}_{2} \mathrm{O}$ with formation of $\mathrm{H}^{+}$and $\mathrm{HCO}_{3}{ }^{-}$, this enzyme could be responsible for the sensitivity of the $\mathrm{CB}$ to $\mathrm{CO}_{2}$ by mediating the changes in extracellular $\mathrm{pH}$. $\mathrm{CB}$ is highly sensitive to sudden changes in arterial blood $\mathrm{PCO}_{2}$, as well as positive or negative variations of $\mathrm{pH}$ [15-17]. The presence of $\mathrm{CA}$ in the $\mathrm{CB}$ has brought about several investigators to speculate its physiologic role in homeostasis of $\mathrm{PO}_{2}, \mathrm{PCO}_{2} / \mathrm{pH}$ [18-20]. CA activity in $\mathrm{CB}$ cells is essential for the speed of chemotransduction and amplitude of the initial response to $\mathrm{CO}_{2}$ and for its subsequent actions $[12,14,17]$. CA was first identified in the CB by Lee and
Mattenheimer in 1964 [3], and, to date, at least $14 \mathrm{CA}$ isozymes have been identified by various methods $[8,9,16$ 18,21,22]. Yamamoto et al. [6] used immunoreactive assay and Western blot analysis to demonstrate the existence of CA isozymes I, II, and III in the rat CB. CA-II was mainly distributed in type I cells and nerve bundles. The results of the present study provide further evidence of CA-II in rat CB. Furthermore, the present study, at first time, provides the total number of CA-II molecules in rat CB.

Using a potentiometric method, Botré et al. identified at least two forms of $\mathrm{CA}$ in rabbit $\mathrm{CB}$. One form of $\mathrm{CA}$ was found in the cytosol, and another was membrane-bound [16]. Later, Yamamoto et al. [19] identified CA isozymes I, II, and III. Porster et al. pointed out that CA-II activity is stronger than CA-I and CA-III [14]. Additionally, Foster et al. observed that CA-II mainly catalyses the $\mathrm{CO}_{2}$ and $\mathrm{H}_{2} \mathrm{O}$ reaction to produce $\mathrm{H}^{+}$and $\mathrm{HCO}_{3}^{-}$, which is critical to bloodgas $\mathrm{CO}_{2}$ exchange. CA-I and CA-III may play a supporting role in this process [23]. In the present study, in order to accurately identify and quantify $\mathrm{CA}$ in the $\mathrm{CB}$ of the rat, only CA-II was studied. We observed it with one-dimensional SDS PAGE electrophoresis and confirmed it with Western blot analysis using an anti-CA-II antibody and radio-labeled ${ }^{125} \mathrm{I}$. Additionally, we calculated the concentration of CA-II in CB tissue. Our study demonstrates that this technique provides a sensitive and accurate way to quantify the CA molecular numbers.

An early study showed that overall CA activity in rabbit $\mathrm{CB}$ was stronger under hypoxic conditions than under normal or hyperoxic conditions [6]. Under chronic hypoxia, the size of the $\mathrm{CB}$ increased significantly as a consequence of the increased number of type I and type II cells [23]. It is 
unclear whether the increased activity of CA or the increased volume of the $\mathrm{CB}$ during chronic hypoxia is due to increased efficiency of CA or to an increase in the number of CAproducing cells. The present study provides a useful technique that will enable us to measure CA concentrations directly and compare them among various conditions.

\section{ACKNOWLEDGEMENT}

The authors wish to thank Dr. Danielle Masursky, Department of Anesthesiology, Upstate Medical University for her editorial assistance.

\section{REFERENCES}

[1] Iturriaga R, Rumsey WL, Mokashi A, Spergel D, Wilson DF, Lahiri S. In vitro perfused-superfused cat carotid body for physiological and pharmacological studies. J Appl Physiol 1991; 70: $1393-400$

[2] Tashian RE. The carbonic anhydrases: widening perspectives on their evolution, expression and function. Bioessays 1989; 10: 18692.

[3] Lee KD, Mattenheimer H. The biochemistry of the carotid body. Enzymol Biol Clin (Basel) 1964; 10: 199-216.

[4] Chegwidden WR, Carter ND. Introduction to the carbonic anhydrases. In: Chegwidden WR, Carter ND, Edward YH, Eds. The carbonic anhydrases. Switzerland: Birkhauser Verlag, Basel 2000; pp. 13-28.

[5] Breton S. The cellular physiology of carbonic anhydrases. JOP 2001; 2: 159-64.

[6] Yamamoto Y, Fujimura M, Nishita T, et al. Immunohistochemical localization of carbonic anhydrase isozymes in the rat carotid body. J Anat 2003; 202: 573-77.

[7] Botrè F, Botre C, Greco A, et al. Potentiometric determination of carbonic anhydrase activity in rabbit carotid bodies: comparison among normoxic, hyperoxic and hypoxic animals. Neurosci Lett 1994; 166: 126-30.

[8] Laemmli UK. Cleavage of structural proteins during the assembly of the head of bacteriophage T4. Nature 1970; 227: 680-5.

[9] Eriksson AE, Liljas A. In: Dodgson SJ, Tashian RE, Gros G, Carter ND, Eds. The carbonic anhydrases: cellular physiology and molecular genetics. New York: Plenum 1991; pp. 33-48.
[10] Jeffery S. In: Dodgson SJ, Tashian RE, Gros G, Carter ND, Eds. The carbonic anhydrases: cellular physiology and molecular genetics. New York: Plenum 1991; pp. 153-62.

[11] Osborne WRA, Tashian RE. An improved method for the purification of carbonic anhydrase isozymes by affinity chromatography. Anal Biochem 1975; 64: 297-303.

[12] Linder M, Wenzel V, Linder D, Stirm S. Structural elements in glycoprotein 70 from polytropic Friend mink cell focus-inducing virus and glycoprotein 71 from ecotropic Friend murine leukemia virus, as defined by disulfide-bonding pattern and limited proteolysis. J Virol 1994; 68: 5133-41.

[13] Wistrand PJ, Wahlstrand T. Rat renal and erythrocyte carbonic anhydrases: purification and properties. Biochim Biophys Acta 1977; 481: 712-21.

[14] Nguyen Q, Stubblebine W, Ragsdale C, et al. Detection of chemiluminescent western blot by reusable phosphor imaging screen. J NIH Res 1993; 5: 79-80.

[15] Battista P, Circolo A, Borsos T. Activation of hemolytic complement by mouse monoclonal IgG1 antibody: comparison with rabbit IgG. Mol Immunol 1985; 22: 215-21.

[16] Eyzaguirre C, Zapata P. Perspectives in carotid body research. J Appl Physiol 1984; 57: 931-57.

[17] Lahiri S, Iturriaga R, Botré F, Gros G, Storey BT, Eds. Carbonic anhydrase: from biochemistry and genetics to physiology and clinical medicine, Weinheim: VCH 1991; p. 404.

[18] Lahiri S, Robertshaw D. International review of physiology: environmental physiology II. Baltimore: University Park Press 1977; vol. XV.

[19] Forster RE II. Carbonic anhydrase and the carotid body. In: Data PG, Acker H, Lahiri S, Eds. Neurobiology and cell physiology of chemoreception. New York: Plenum 1993; pp. 137-47.

[20] Iturriaga R, Lahiri S. In: Data PG, Acker H, Lahiri S, Eds. Neurobiology and cell physiology of chemoreception. New York: Plenum 1993; pp. 227-40.

[21] Ridderstrale Y, Hanson MA. Histochemical localization of carbonic anhydrase in the cat carotid body. Ann N Y Acad Sci 1984; 429: pp. 398-400.

[22] Torrance RW, Bartles EM, Mclaren AJ, et al. In: Data PG, Acker H, Lahiri S, Eds. Neurobiology and cell physiology of chemoreception. New York: Plenum 1993; pp. 79-88.

[23] McGregor KH, Gil J, Lahiri S. A morphometric study of the carotid body in chronically hypoxic rats. J Appl Physiol 1984; 57: 143038 .

Received: December 22, 2008

Revised: March 11, 2009

Accepted: March 16, 2009

(C) Di Tano et al.; Licensee Bentham Open.

This is an open access article licensed under the terms of the Creative Commons Attribution Non-Commercial License (http://creativecommons.org/licenses/by$\mathrm{nc} / 3.0 /$ ) which permits unrestricted, non-commercial use, distribution and reproduction in any medium, provided the work is properly cited. 